\title{
Syringe guide for instrumental insemination apparatus of queen bees (Apis mellifera $L$ )
}

\author{
J Woyke \\ Agricultural University, SGGW,Bee Culture Division, Nowoursynowska 166, \\ Warsaw 02-766, Poland
}

(Received 9 June 1990; accepted 5 November 1990)

\begin{abstract}
Summary - The syringe guide consists of a long thick wire rod fixed to the syringe holder. This rod allows an inseminator to make all syringe-tip movements by moving the guide with his left hand. The right hand is then free to insert the syringe-tip and semen into the vagina, without the inconvenience of removing the hand from the syringe. The guide enables queens to be inseminated more quickly and with less discomfort. Construction of the guide is simple and economical.
\end{abstract}

Apis mellifera / instrumental insemination / apparatus

\section{INTRODUCTION}

Instrumental insemination is now used on a large scale for mass insemination of queen bees. One inseminator inseminates scores of queens per day. It is therefore important to improve the apparatus in such a way as to make insemination easy, quick and with a minimum of discomfort. Of course, the collection of semen from the drones is the most time-consuming procedure.

The procedure of introduction of the syringe tip into the queen's vaginal orifice can be improved upon. Originally, Mackensen and Roberts (1948) as well as Laidlaw $(1944,1977)$ used the vaginal probe to lower the vaginal valve-fold. The tip was then introduced behind that probe. However to make insemination faster and easier, professional inseminators have discontinued using the valve-fold probe.

Introduction of the syringe-tip into the queen's genital tract requires very precise movements. In Mackensen's apparatus, the tip was lowered by pushing the syringe down. Inclination of the syringe (dorso-ventral movements in relation to the queen) was also performed directly by hand. The transversal movements (right and left in relation to the queen) were made by revolving the entire syringe block, with the syringe in the holder, around the vertical support. This type of apparatus is still used by nearly everyone performing instrumental insemination of bees in the USA (Harbo, 1989). Due to the lever principle, small movements made by hand at the level of the syringe block holder result in large movements at the tip of the needle. These hand-directed 
movements made it difficult for the inexperienced to introduce the tip into the genital orifice. Vesely (1966) therefore added a screw adjustement to the syringe holder. By turning a screw, the syringe inclination was altered, and the tip of the needle was moved dorso-ventrally. But the transversal movements of the tip still had to be carried out by hand, rotating the block holder with the syringe around the vertical support. This procedure was improved upon by Schley (1983), who constructed another adjustment, which enables transversal movements of the syringe with the tip. Swienty in Denmark has constructed a precise apparatus provided with 3 micromanipulators (Holm, 1986). Each manipulator moves one of the 2 hooks or the syringe. The movements are very precise; however, the hook's possibilities are so limited that the queen's abdomen cannot be opened by them. Pointed forceps have to be used to open the abdomen. Dorsoventral or vertical syringe movements can be made with the help of the micromanipulator. But transversal movements of the hooks or the syringe have to be made by turning additional screws. Different modifications of the apparatus for instrumental insemination have been described in the latest manual on instrumental insemination (Moritz, 1989).

All the above improvements have certainly presented some progress in the development of the apparatus for instrumental insemination. Nevertheless, all these adjustements did not resolve the problems connected with the movements and introduction of the syringe tip into the genital orifice of the queen. All tip movements as well as the introduction of the tip into the genital orifice had to be directed by the same hand. This required removing the right hand from the syringe or the micromanipulator to turn the screw discs for additional adjustments, and either looking away from the microscope or turning the discs without looking. The syringe holder or the micromanipulator became complicated, difficult to construct and expensive to buy.

\section{RESULTS}

\section{Construction of the syringe guide}

A simple and useful syringe guide has been constructed in Poland (fig 1). It allows all tip movements to be directed with one hand, while the other hand is used to introduce the syringe tip into the queen's genital orifice. The guide consists of a long thick wire rod fixed to the syringe holder (fig 2). Due to the lever principle, large movements at the end of the guide result in small precise movements at the tip of the syringe needle.

Before the guide can be fixed to the apparatus, the syringe holder must be fixed permanently to the head of the bolt on which the holder rotates vertically in the syringe block (fig 3a). The bolt should be also longer than in the Mackensen apparatus. It should protrude $2 \mathrm{~cm}$ above the nut which holds the spiral spring between it and the block.

Next a wire $\approx 26 \mathrm{~cm}$ long and $6 \mathrm{~mm}$ thick is selected. The wire can be $>6 \mathrm{~mm}$ thick, but should not be too thin, because it might then be too flexible for precise movements. A transversal hole should be drilled near one end of the rod (fig 3t). The bolt of the queen holder slips through the hole in the guide, and the guide is fastened to the bolt with 2 check nuts (fig 3 n). The 2 nuts hold the end of the rod between them. It is possible to work with the guide fixed in this manner, but it is better to use a set screw which keeps the guide from slipping on the bolt. The set screw penetrates the proxi$\mathrm{mal}$ end of the guide (fig $3 \mathrm{~s}$ ). A hole is 


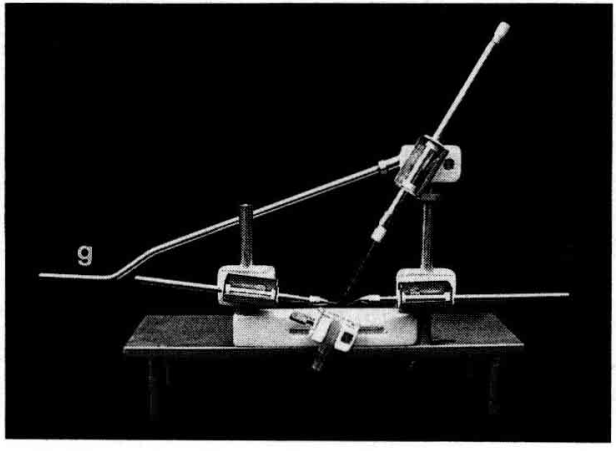

Fig 1. Apparatus for instrumental insemination of queen bees equipped with a syringe guide (g).

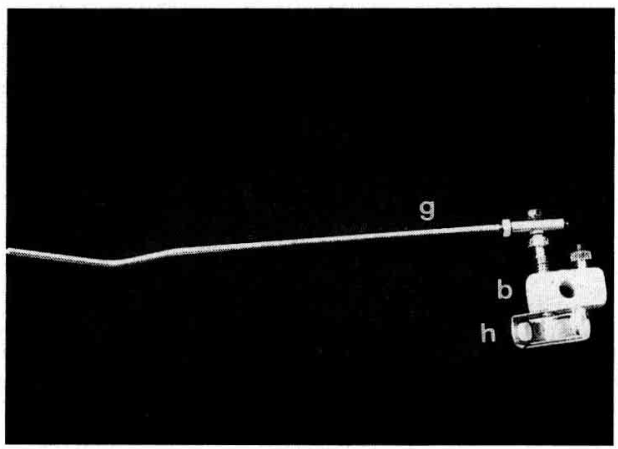

Fig 2. Syringe guide (g) with syringe block (b) and syringe holder (h).

drilled from the end of the rod along its axis to the hole for the bolt.

\section{Procedure of queen insemination with the help of the guide}

Insemination of the queen is facilitated both by the use of the guide, and rejection of the valve-probe. First, the tip is filled with semen, and the queen is prepared for instrumental insemination as usual. All the

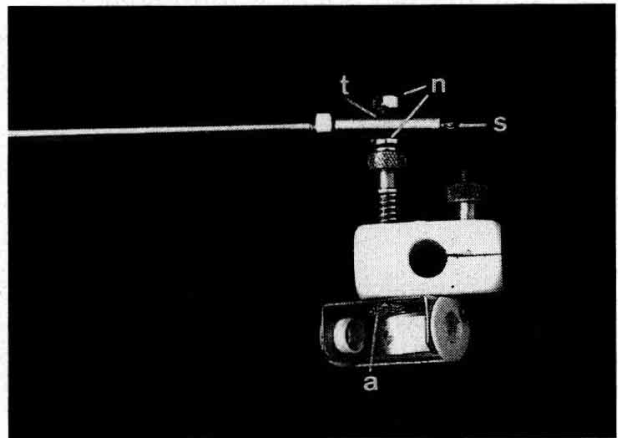

Fig 3. Details of syringe guide, block and holder. Head of bolt fixed to syringe holder (a), transversal hole in end of guide through which the bolt is slipped in (t), check nuts on bolt to fix the guide to bolt $(n)$, set screw fixing guide to bolt (s).

movements at the tip of the needle are made with the aid of the guide by moving it with the left hand. The entire procedure of the introduction of the tip into the queen's vagina is made by the right hand without removing it from the syringe.

First, the tip of the needle is positioned near the dorsal edge of the vaginal orifice. Next it is inserted $\approx 0.5 \mathrm{~mm}$ into the vagina. Then the distal end of the guide is lifted with the left hand. As a result, the tip of the needle is moved ventrally. During that movement the valve-fold is pressed against the ventral side of the vagina, resulting in opening of the entrance to the median oviduct. The tip is then inserted $\approx$ $1.5 \mathrm{~mm}$ deeper, and the semen injected through the median oviduct into both lateral oviducts.

It is even possible to make the 2 steps of tip introduction in one continuous insertion. While the right hand monitors the introduction of the syringe tip into the vagina, the left hand ensures that at the same time the tip is moved dorso-ventrally with the aid of the guide. After the semen has been 
injected into the queen's reproductive organs, the tip is withdrawn and insemination is completed.

\section{ACKNOWLEDGMENTS}

The present version of the guide was elaborated at the Bee Division of the Agricultural University in Warsaw. We acknowledge the invaluable help of Mr Ślek and Dr Jaśiński in devising and improving the guide.

Résumé - Guide pour la seringue de l'appareil pour l'insémination artificielle des reines d'abeilles. L'introduction de la pointe dans le tractus génital de la reine nécessite des mouvements très fins de la seringue. Dans l'appareil de Mackensen, l'inclinaison de la seringue était obtenue manuellement par des déplacements directs de celle-ci et les mouvements transversaux en faisant pivoter tout le bloc de la seringue autour du support vertical. Par le principle du levier, de petits mouvements imprimés manuellement au niveau du bloc seringue produisaient des mouvements amples à la pointe de la seringue remplie de sperme.

C'est pourquoi Vesely (1966) a construit un support de seringue avec réglage par vis, qui permet de modifier l'inclinaison de la seringue. Schley (1983) a construit un autre support qui permet les mouvements transversaux de la pointe. Mais la manipulation des vis des supports comme l'introduction même de la pointe doivent être faites avec la même main. II faut pour cela que la main droite lâche la seringue pendant l'insémination. Le support devenait très complexe et coûteux.

Un guide pour la seringue, simple et pratique, a été construit à l'Institut apicole de l'université d'agriculture de Varsovie (fig
$1 \mathrm{g).}$. Ce guide consiste en une longue tige métallique fixée au support de la seringue (fig $2 \mathrm{~h} ; \mathrm{b}=$ bloc seringue). Par le principe du levier, de larges mouvements imprimés à l'extrêmité le guide produisent des petits mouvements précis à la pointe de la seringue. Le support de la seringue doit rester constamment relié à la tête de la vis à laquelle le guide est fixé (fig 3a).

Pendant l'insémination artificielle de la reine, tous les mouvements de l'extrémité de la pointe sont exécutés avec le guide en le déplaçant avec la main gauche. Tout le travail d'introduction de la pointe dans le vagin de la reine est réalisé par la main droite sans avoir à lâcher la seringue. Ceci permet d'inséminer des reines plus rapidement et plus facilement. La construction de ce guide est plus facile et moins coûteuse que celle des autres dispositifs.

\section{Apis mellifera / insémination artificielle / appareil}

\section{Zusammenfassung - Leitstab für die Spritze des Apparates zur Besamung von Bienenköniginnen. Die Einführung der Spitze in den Eileiter der Königin erfor- dert sehr feine Bewegungen der Spritze. Bei dem ursprünglichen Mackensen- Apparat wurde die Neigung der Spritze durch direkte Bewegung mit der Hand verändert. Die Bewegungen in transversa- ler Richtung wurden durch Drehung des ganzen Spritzenblocks mit der Spritze um den senkrechten Spritzenhalter bewirkt. In- folge des Hebelprinzips führten geringe Bewegungen, ausgeführt von Hand am Spritzenblock, zu großen Bewegungen der mit Samen gefüllten Spritze. Das hatte Schwierigkeiten bei der Einführung der Spritze in die Genitalöffnung der Königin zur Folge.}

Deshalb konstruierte Vesely (1966) einen Spritzenhalter mit Stellschraube, 
durch welche die Neigung der Spritze verändert werden konnte. Schley (1983) konstruierte eine andere Vorrichtung, welche Bewegungen der Spritze in transversaler Richtung ermöglichten. Aber sowohl die Betätigung der Schrauben dieser Vorrichtung wie die Einführung der Spritze selbst in die Scheide hatten mit derselben Hand zu erfolgen. Deshalb mußte man während des Besamungsvorganges den Griff der rechten Hand zur Bedienung der Schrauben am Spritzenblock wechseln. Der Spritzenhalter wurde sehr kompliziert und teuer.

Am Bieneninstitut der Landwirtschaftlichen Universität Warschau wurde eine einfache und nützliche Leitvorrichtung für die Spritze konstruiert (Abb 1g). Die Vorrichtung besteht aus einem langen, dicken Metallstab, der an dem Spritzenhalter befestigt ist (Abb $2 h ; b=$ Spritzenblock). Entsprechend den Hebelgesetzen führen ausgiebige Bewegungen am Ende des Leitstabes zu geringen, feinen Bewegungen der Spritzenspitze. Der Spritzenhalter muß dabei fest mit dem Kopf der klemm sckraube verbunden bleiben (Abb $3 a$ ); zur welche der Laitstab befestig ist.

Während der instrumentellen Besamung der Königin werden alle Bewegungen des Spritzenendes mit Hilfe des Leitstabes durch Betätigung mit der linken Hand gesteuert. Der gesamte Vorgang der Einführung der Spritze in die Scheide der Königin erfolgt mit der rechten Hand, welche dabei ständig an der Spritze verbleiben kann. Dadurch kann die Besamung der Königinnen rascher und bequemer durchgeführt werden als mit jedem anderen Apparat. Die Konstruktion des
Leitstabes ist einfacher und billiger als andere Vorrichtungen.

\section{Apis mellifera / instrumentelle Besam- ung / Apparat}

\section{REFERENCES}

Harbo JR (1989) Equipment used in the USA. In: The Instrumental Insemination of the Queen Bee (Moritz RFA, ed) Apimondia, Bucharest, 47-51

Holm E (1986) Artificial Insemination of the Queen Bee. A Manual for the Use of Swienty's Insemination Apparatus. Publ Eigil Holm, Byskovsvej 4, DK-8751 Denmark

Laidlaw HH Jr (1944) Artificial insemination of the queen bees (Apis mellifica L). Morphological basis and results. $J$ Morphol 74, 429465

Laidlaw HH Jr (1977) Instrumental Insemination of Honey Bee Queens. Dadant and Sons, Hamilton, IL

Mackensen O, Roberts WC (1948) A Manual for the Artificial Insemination of Queen Bees. USDA, Bur Entomol Plant Quarant, ET-250

Moritz RFA (ed) (1989) The Instrumental Insemination of the Queen Bee. Apimondia, Bucharest

Schley P (1983) Praktische Anleitung zur instrumentellen Besamung von Bienenkönigiennen. Selbstverlag, Giessen

Vesely $V(1966)$ Description of and handling with, the insemination equipment used at the course on artificial insemination of queen bees. In: Manual on Artificial Insemination of the Queen Bees (Woyke J, Ruttner F, Vesely V, eds) Dol (Czech), Vyzkumny Ustav Vcelarsky, 35-67

Vesely V (1969) Modification of the MackensenRoberts apparatus. In: The Instrumental Insemination of the Queen Bee (Ruttner F, ed) Apimondia, Bucharest, 35-37 